\title{
Physiopathological Aspects of Sellar Epidermoid Cyst Determining Endocrine Disturbances: A Case Report
}

\section{Aspectos fisiopatológicos de cisto epidermoide selar determinando alterações endócrinas: Relato de caso}

\author{
Eduardo Cambruzzi ${ }^{1}$ Nelson Pires Ferreira ${ }^{2}$ Gabriel Barcellos ${ }^{2}$ Pablo Fruet $^{2}$ \\ ${ }^{1}$ Department of Neurosurgery, Hospital São José, Complexo \\ Hospitalar Santa Casa, Porto Alegre, Rio Grande do sul, Brazil \\ 2 Department of Pathology, Hospital São José, Complexo Hospitalar \\ Santa Casa, Porto Alegre, Rio Grande do sul, Brazil

\begin{abstract}
Address for correspondence Eduardo Cambruzzi, Complexo Hospitalar Santa Casa de Misericórdia de Porto Alegre, Hospital São José, Av. Independência, 75, Porto Alegre, RS, 90035-972, Brazil
\end{abstract} \\ (e-mail: dudacambruzzi@yahoo.com.br).
}

Arq Bras Neurocir 2019;38:210-214.

\author{
Abstract \\ Keywords \\ - epidermoid cyst \\ - sellar region \\ - pathology \\ - central nervous \\ system cysts \\ - brain neoplasms

\section{Resumo} \\ Palavras-chave \\ - cisto epidermoide \\ - região sellar \\ - patologia \\ - cistos do sistema \\ nervoso central \\ - neoplasias cerebrais
}

Epidermoid cysts (ECS) of the central nervous system (CNS) constitute benign circumscribed lesions that are more common in lateral than in midline sites. Epidermoid cysts of the CNS arise more frequently in the cerebellopontine angle, around the pons, near the sella, within the temporal lobe, in the diploe, and in the spinal canal. Most common tumoral lesion of sellar region is pituitary adenoma, and sellar cystic epithelial masses may be difficult to differentiate based only on clinical and imaging findings. Epidermoid cysts are covered by keratinized squamous epithelium and are usually filled with keratin lamellae. The process is, for the most part, maldevelopmental in origin, presumably arising from trapped surface ectodermal elements in association with the developing CNS during the closure of the neural groove or formation of the secondary cerebral vesicles. In the present study, the authors describe a case of sellar epidermoid cyst producing endocrine alterations and visual disturbance in a 35 years woman, and review the physiopathological and diagnostic criteria of this lesion.

Os Cistos Epidermoides (CE) do sistema nervoso central (SNC) constituem lesões benignas circunscritas, que são mais comuns na linha media do que em regiões laterais. Os CE do SNC ocorrem com maior frequência no ângulo pontocerebelar, ao redor da ponte, próximo à sela, no lobo temporal, na diploe e no canal espinhal. A lesão tumoral mais comum da região selar é o adenoma hipofisário, e as massas epiteliais císticas selares podem ser difíceis de diferenciar baseando-se apenas nos achados clínicos e de imagem. Os CE são cobertos por epitélio escamoso queratinizado e geralmente são preenchidos por lamelas de queratina. O processo é, em sua maior parte, de origem

DEduardo Cambruzzi's ORCID is https://orcid.org/0000-0003-41019325.

received

March 13, 2019

accepted

May 27, 2019
DOI https://doi.org/

$10.1055 / \mathrm{s}-0039-1693684$. ISSN 0103-5355.
Copyright (e) 2019 by Thieme Revinter

Publicações Ltda, Rio de Janeiro, Brazil
License terms

(c) $(1) \$$ 
malformativa, presumivelmente em decorrência de elementos ectodérmicos de superfície aprisionados no desenvolvimento do SNC durante o fechamento do sulco neural ou na formação das vesículas cerebrais secundárias. Neste trabalho, os autores descrevem um caso de cisto epidermoide selar, que determinou alterações endócrinas e distúrbios visuais em uma mulher de 35 anos, e revisam os critérios fisiopatológicos e diagnósticos dessa lesão.

\section{Introduction}

Epidermoid cyst (EC) is a benign cystic lesion covered by mature keratinized squamous epithelium and occupied by keratin lamellae, without adnexal structures in its wall. The process corresponds to $\sim 0.2$ to $1.8 \%$ of all primary intracranial tumors and are 4 to 9 times as common as dermoid cysts. ${ }^{1-4}$ Most ECs compromising the central nervous system (CNS) are extraaxial, leptomeningeal lesions, with the cerebellopontine angle ( $40-50 \%$ of patients) being the most common location. Epidermoid cysts can also be found in the $4^{\text {th }}$ ventricle (17\%), in the sellar/parasellar region (10-15\%), in the cerebral hemispheres, in the brainstem, in the skull, and in the spine. ${ }^{1-6}$

Most tumoral and non-tumoral sellar lesions are solid process, and pituitary adenoma is the most common tumor in this topography. Cystic sellar lesions are not as frequent as pituitary adenoma, and Rathke cysts and craniopharyngioma are usually the final diagnosis. Epidermoid cysts of the CNS present slowly progressive symptoms, such as headache and cranial nerve dysfunction. ${ }^{2,3,6-11}$ Epidermoid cysts arise from ectodermal inclusion during the neural tube closure in the third to the fifth week of embryogenesis. They have an excellent long-term survival, and gross total resection is usually curative. . $^{1,2-8-11}$

The authors describe a case of sellar EC presenting endocrine alterations and progressive visual disturbance in a 35 years female patient, and discuss the most common physiopathological findings of this lesion, and its differential diagnosis.

\section{Case History}

A female patient, 35 years old, presenting clinical complaint of amenorrhea in the previous 20 months was referred to the neurosurgical service due to a sellar cystic mass. The patient had been accompanied by an endocrinologist during this period, with regular use of prednisone $(5 \mathrm{mg} /$ day) and levothyroxine ( $100 \mathrm{ucp} /$ day). In the last 4 months, the patient complained of visual disturbances. Magnetic resonance imaging showed an increase in the dimensions of the process, which also exhibited hemorrhagic areas, and measured $2.7 \times 2.0 \times 1.7 \mathrm{~cm}$ (-Fig. 1). The campimetry showed peripheral visual loss. On physical examination, no signs of neurological deficits were found. Chest and abdominal computed tomography (CT) did not identify significant alterations. A clinical hypothesis of pituitary adenoma with degenerative changes was established, and resection of the lesion was proposed. The transsphenoidal approach identified an expansive lesion compromising the sellar region

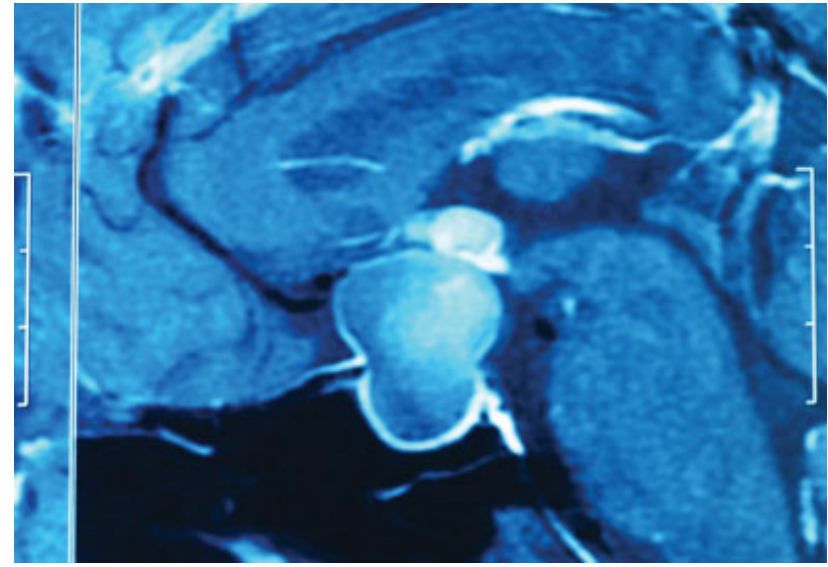

Fig. 1 Epidermoid cyst: preoperative magnetic resonance imaging showing an expansive sellar process.

(-Fig. 2), with significant compression of the optic chiasm. A gross total resection was performed. The pathological specimen was composed of some elastic, pale gray, irregular fragments of tissue, the largest one measuring $1.1 \times 1.0$ $\times 0.8 \mathrm{~cm}$. At microscopy, a benign cystic lesion covered by keratinized stratified squamous epithelium and a fibrous wall was found ( - Fig. 3). The process was filled with keratin lamellae and dystrophic tissue, and was contiguous to normal hypophyseal tissue. The diagnosis of sellar EC was then

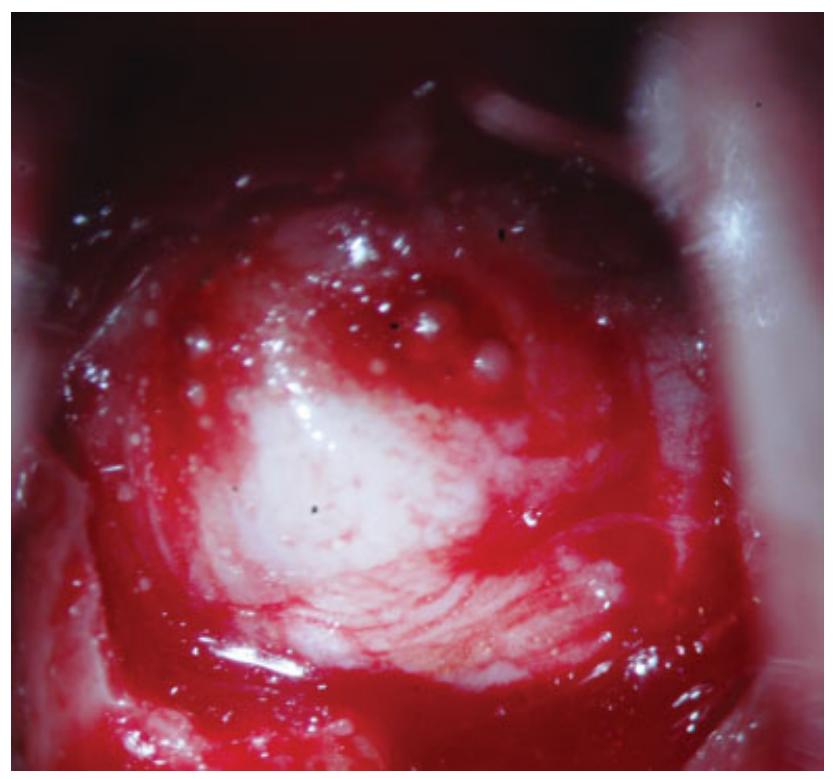

Fig. 2 Sellar epidermoid cyst: a pale gray expansive lesion. 


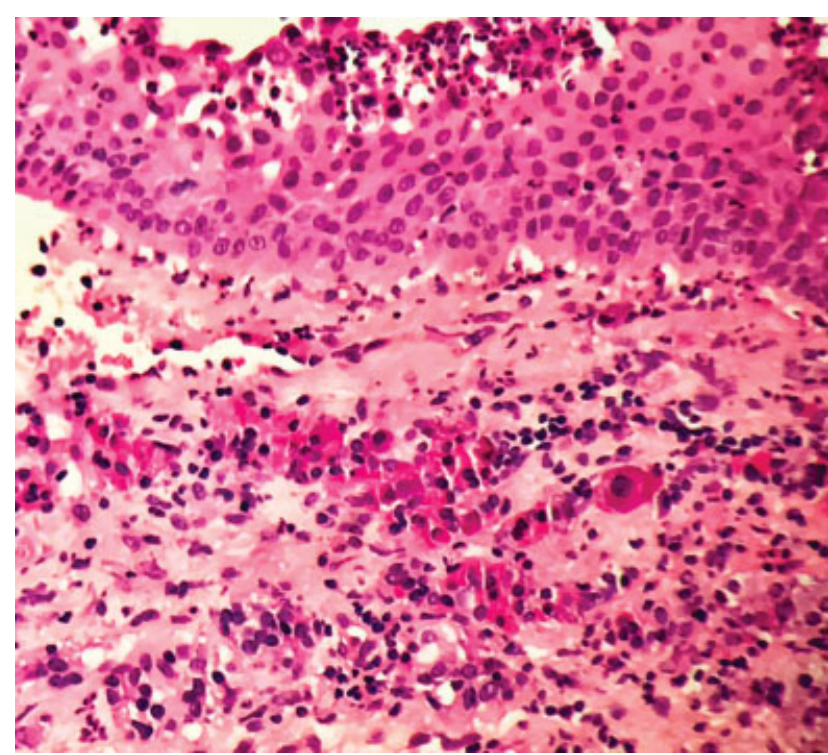

Fig. 3 Sellar epidermoid cyst: A benign cystic lesion covered by keratinized stratified squamous epithelium, hematoxylin-eosin, 200x.

established. In the immediate postoperative period, the patient developed diabetes insipidus, which was controlled with the use of desmopressin. After a follow-up of 8 months, no signs of recurrence were identified on radiological evaluation, and the patient was asymptomatic. During this period of clinical follow-up, the patient presented normal serum levels for pituitary hormones and estrogen. The use of prednisone, levothyroxine, and desmopressin was then discontinued.

\section{Discussion}

Epidermoid cysts are rare processes that probably represent developmental lesions resulting from embryologic displacement of ectoderm into the CNS tissue. ${ }^{6}$ The pattern of embryological formation of the hypothalamic-pituitary-axis plays a major role in its propensity in the development of sellar ECs. ${ }^{3,4,12-16}$ Neurulation can be divided broadly into primary and secondary phases. In primary neurulation, which occurs throughout the future brain, the neural tube is formed by neural folding. The formation and closure of the neural tube occur between 18 and 26 days postconception. Closure of the neuropores occurs at the end of this developmental process around day $26 .^{12-14}$ The current hypothesis is that there are multiple local (possibly five) neural tube closure sites. Primary neurulation begins with neural induction, leading to the appearance of the neural plate, a thickened dorsal midline ectodermal structure. The neural folds converge toward the midline and fuse, forming the neural tube on day 22 in the future cervical/occipital boundary. Initially, the wall of the neural tube is composed by a columnar pseudostratified neuroepithelium. The skull base and facial skeleton are derived from the neural crest. $^{12-14}$ The pituitary diverticulum of the stomodeum roof (oral ectoderm) will give rise to the adenohypophysis. The neurohypophyseal diverticulum of the diencephalon floor (neuroectoderm) will give rise to the neurohypophysis. Adenohypophyseal tissue can be trapped anywhere along the path followed by Rathke's pouch during fetal development. ${ }^{12-14}$ Two general patterns of neural tube malformation are encountered. In the first, there is a failure of the developing neural tube to close properly, with secondary disruption of the axial mesoderm, which determines abnormal neuroectodermal tissue protruding through a secondary defect in mesenchymal structures. ${ }^{12-14}$ In the second pattern, the primary embryonic defect is related to the development of the axial mesoderm, and the neural tube is closed. During these development cellular events, including migration, proliferation and differentiation, abnormal ectoderm tissue can be associated with the future development of midline ECs. Neural tube defects include meroencephaly, craniorachischisis, occult spina bifida, meningomyelocele, encephalocele, and myeloschisis. ${ }^{12-14}$ Unfrequently, CNS ECs arise from implants of epithelium carried into the meninges during percutaneous aspiration of the subdural or subarachnoid space. A proportion of spinal ECs, especially those in the lumbosacral region, occur in conjunction with spina bifida or diastematomyelia. Unlike dermoid cysts, ECs often occur laterally, without a preference for midline sites. $3,4,12-18$

Intracranial ECs account for only $1 \%$ of all intracranial tumors, if suprasellar examples are excluded. The cerebellopontine angle and parapontine regions are the most common intracranial site for ECs. ${ }^{2,3,8,11,15-17}$ Epithelial rests may be transplanted to regions such cerebellopontine angle by the lateral migrating otic capsule or developing neurovasculature. Intraspinal lesions are less common. Rarely, ECs are located in the cranial diploe of the middle ear region or frontal bone, where they present as a lytic defect. $2,3,7,8,11,15-18$

The authors reported a female patient with clinical complaint of amenorrhea due to a sellar EC. Symptoms associated to sellar EC can be related to a slow growing mass effect, and include focal neurologic deficits or nonlocalizing signs such as headache, visual alterations, and pituitary dysfunction. ${ }^{15,18-22}$ Epidermoid cysts tend to surround adjacent structures, and its rupture can produces chronic inflammation of the leptomeninges or ependyma. ${ }^{15,18-21}$ Sellar/suprasellar ECs can determine disturbances in the release and/or production of hormones, because the compressive effect of the process may affect the physiology of the pituitary gland or even determine hypothalamic disorders. Since any hypothalamic hormone can be synthesized in more than one hypothalamic nucleus, and a single nucleus may express several hormones, different clinical signs can be identified. ${ }^{19}$ Alterations in the suprachiasmatic nucleus of the hypothalamus can be associated with decrease in gonadotropin release. ${ }^{19}$ Lesions of the supraoptic nuclei can decrease the synthesis of oxytocin and vasopressin. Damage of the ventromedial nucleus results in obesity; conversely, destruction of the ventrolateral nucleus causes anorexia and cachexia. The arcuate (infundibular) nucleus plays a major role in the modulation of anterior pituitary function. The paired medial and lateral nuclei are associated with autonomic function, in special temperature control and olfaction. ${ }^{19}$ The posterior nucleus 
has been implicated in temperature regulation, and its large neurons are thought to be the source of hypothalamic efferents, which descend to the reticular formation of the brainstem. Increase of prolactin serum levels can be attributed to injury of the arcuate nucleus, which controls the secretion of dopamine (an inhibitor of prolactin secretion). ${ }^{19}$ Hyperprolactinemia exerts an inhibitory activity on the positive feedback effect of estradiol on gonadotropin-releasing hormone (GnRH) secretion. Increase of prolactin seems to depend on decrease of factors that inhibit prolactin secretion, such as dopamine produced by the arcuate nucleus of the hypothalamus (probably compressed by EC). In females, hyperprolactinemia can determine galactorrhea, oligomenorrhea/amenorrhea and infertility. ${ }^{19}$

Sellar ECs determining hypothalamic hyperfunction syndromes can be related to early puberty, ectopic production of hypothalamic hormones, and inappropriate secretion of antidiuretic hormone. Hypofunction syndromes can be associated to different endocrine disorders like hypothalamic dwarfism, diencephalic syndrome, obesity, hypothalamic hypogonadism, amenorrhea, diabetes insipidus, and hypopituitarism. ${ }^{19}$ Other alterations include changes in appetite and thirst, hypothermia, hyperthermia, disorders in the pattern of sleep and wakefulness, behavioral disorders, visual disturbances, spasticity, hyperreflexia, ataxia, and uncoordinated movements. $^{19}$

On CT, most sellar ECs are circumscribed, nonenhancing, extraaxial lesions, which can exhibit calcification areas around $10 \%$ of cases. Magnetic resonance imaging findings include variable intensity on T1-weighted images, and hyperintensity on fluid-attenuated inversion recovery (FLAIR) and T2-weighted images. ${ }^{1,4,6,10,15,17,19,20}$ On gross, sellar ECs are a pale-gray, uniloculated, translucent lesion, which can measure from a few millimeters to over $4 \mathrm{~cm}$ in diameter. ${ }^{1,4,6,9,15,16,21,22}$ At microscopy, ECs are covered by a mature keratinizing squamous epithelium, and the lumen is occupied by lamellae of keratin. No evidence of atypias can be found and the wall is constituted by connective tissue. Mitotic figures are very rare and foreign body giant cell reaction is present in cases of a ruptured cyst. Sellar EC shows positive immunoexpression for keratins and negative pattern for glial fibrillary acidic protein (GFAP) and synaptophysin. 1,4,6,9,15,20,22

In the sellar/suprasellar region, the differential diagnosis of EC includes dermoid cysts, craniopharyngioma, enterogenous cyst, neuroglial cyst, arachnoid cysts, endodermal cyst, Rathke cleft cyst with extensive squamous metaplasia, eventually metastatic well differentiated squamous cell carcinoma, and mature teratoma. ${ }^{4-6,9,11,15,20,23,24}$ Dermoid cysts (DCs) arise more commonly in the midline of infants, being related to fontanel, the fourth ventricle, or the spinal canal. Dermoid Cyst (DM) exhibit a thick wall and contain adnexal structures, such as hair follicles and sebaceous glands. ${ }^{4-6,10,13,20-22}$ Adamantinomatous craniopharyngioma exhibits a thick, complex, palisaded epithelium, while papillary craniopharyngioma shows a thick epithelium disposed in irregular papillae with fibrovascular core. Papillary craniopharyngioma lacks keratohyalin granules and anucleate squames. Mature teratoma are more frequently solid masses constituted by cartilaginous tissue, sebaceous gland, and mature dermis and epidermis. ${ }^{4-6,10,15,21,24,25}$

The curative treatment for sellar ECs is gross total surgical removal by transsphenoidal approach, but the presence of dense adherence of the lesion to the adjacent structures can limit the complete resection of the cyst. ${ }^{2-4,8,16,25}$ The most common postoperative complications are diabetes insipidus, endocrine disturbances, and chemical meningitis, due to leakage of keratin into the cerebral spinal fluid (CSF) pathways. ${ }^{2-4,6,8,16}$ After a follow-up of 9 months, no signs of recurrence or endocrine disturbances were noted.

\section{Conflict of Interest}

The authors declare that there are no conflicts of interest.

\section{References}

1 Ravindran K, Rogers TW, Yuen T, Gaillard F. Intracranial white epidermoid cyst with dystrophic calcification - A case report and literature review. J Clin Neurosci 2017;42:43-47

2 Forbes JA, Banu M, Lehner K, et al. Endoscopic endonasal resection of epidermoid cyst involving the ventral cranial base. J Neurosurg 2018;8:1-10

3 Nakassa ACI, Chabot JD, Snyderman CH, Wang EW, Gardner PA, Fernandez-Miranda JC. Complete endoscopic resection of a pituitary stalk epidermoid cyst using a combined infrasellar interpituitary and suprasellar endonasal approach: case report.J Neurosurg 2018; 128(02):437-443

4 Fomichev D, Kalinin P, Kutin M, Sharipov O. Endoscopic endonasal surgery of epidermoid cysts of the chiasmatic region. World Neurosurg 2016;96:159-164

5 Takeda N, Fujita K, Katayama S, et al. [Intrasellar epidermoid cyst]. No To Shinkei 2000;52(07):625-628

6 Cambruzzi E, Presa K, Silveira LC, et al. Epidermoid cyst of the posterior fossa: a case report. J Bras Patol Med Lab 2011;47(01):79-82

7 Baskin DS, Wilson CB. Transsphenoidal treatment of non-neoplastic intrasellar cysts. A report of 38 cases. J Neurosurg 1984;60(01):8-13

8 Hasegawa M, Nouri M, Nagahisa S, et al. Cerebellopontine angle epidermoid cysts: clinical presentations and surgical outcome. Neurosurg Rev 2016;39(02):259-266, discussion 266-267

9 Abele TA, Yetkin ZF, Raisanen JM, Mickey BE, Mendelsohn DB. Nonpituitary origin sellar tumours mimicking pituitary macroadenomas. Clin Radiol 2012;67(08):821-827

10 Zada G, Lin N, Ojerholm E, Ramkissoon S, Laws ER. Craniopharyngioma and other cystic epithelial lesions of the sellar region: a review of clinical, imaging, and histopathological relationships. Neurosurg Focus 2010;28(04):E4

11 Santosh IP, Rajshekhar V. Galactorrhea as the sole presenting symptom of a posterior third ventricular epidermoid cyst. Surg Neurol 2001;55(01):46-49, discussion 49

12 Dias MS, Walker ML. The embryogenesis of complex dysraphic malformations: a disorder of gastrulation? Pediatr Neurosurg 1992;18(5-6):229-253

13 Sano K. Intracranial dysembryogenetic tumors: pathogenesis and their order of malignancy. Neurosurg Rev 2001;24(04):162-167, discussion 168-170

14 Greene ND, Copp AJ. Neural tube defects. Annu Rev Neurosci 2014;37:221-242

15 Burger PC, Scheithauer BW. Benign Cystic Lesions. In: Tumors of the Central Nervous System, Armed Forces Institute of Pathology - Atlas of Tumor Pathology, vol. 7. Washington: ARP Press; 471-4902007

16 Roh TH, Park YS, Park YG, Kim SH, Chang JH. Intracranial squamous cell carcinoma arising in a cerebellopontine angle epidermoid cyst: A case report and literature review. Medicine (Baltimore) 2017;96 (51):e9423 
17 Poyuran R, Mahadevan A, Sagar BK, Saini J, Srinivas D. Chordoid glioma of the third ventricle with an epidermoid cyst: coexistence or common histogenesis. Int J Surg Pathol 2016;24(07): 663-667

18 Huo CW, Caputo C, Wang YY. Suprasellar keratinous cyst: A case report and review on its radiological features and treatment outcome. Surg Neurol Int 2018;9:15

19 Cambruzzi E, Pegas KL, Silveira LC. Pilocytic astrocytoma of sellar/ suprasellar region determining endocrine manifestations. J Bras Patol Med Lab 2013;49(02):139-142

20 Tuna H, Torun F, Torun AN, Erdogan A. Intrasellar epidermoid cyst presenting as pituitary apoplexy. J Clin Neurosci 2008;15(10): 1154-1156
21 Jiang $\mathrm{x}$, Chen Y, Zhou et al. . Surgical resection of pineal epidermoid cyst contributed to relieving schizophrenia symptoms. World Neurosurg 2018;113:304-307

22 Verkijk A, Bots GT. An intrasellar cyst with both Rathke's cleft and epidermoid characteristics. Acta Neurochir (Wien) 1980;51 (3-4):203-207

23 Chung LK, Beckett JS, Ong V, et al. Predictors of outcomes in fourth ventricular epidermoid cysts: A case report and a review of literature. World Neurosurg 2017;105:689-696

24 Osborn AG, Preece MT. Intracranial cysts: radiologic-pathologic correlation and imaging approach. Radiology 2006;239(03):650-664 25 Boggan JE, Davis RL, Zorman G, Wilson CB. Intrasellar epidermoid cyst. Case report. J Neurosurg 1983;58(03):411-415 